\title{
PENGARUH PENGGANTIAN JAGUNG GILING DENGAN SENGAUK DALAM RANSUM YANG MENGANDUNG STARPIG DISUPLEMENTASI DENGAN DAUN SALAM (Syzygium polyanthumWalf) TERHADAP EFISIENSI PENGGUNAAN RANSUM DAN PROFIL LIPIDA DARAH AYAM KAMPUNG
}

\author{
TJOKORDA GEDE BELAWA YADNYA DAN I WAYAN WIRAWAN \\ Fakultas Peternakan, Universitas Udayana,Denpasar \\ e-mail: belawayadnya_fapet@yahoo.com
}

\begin{abstract}
ABSTRAK
Penelitian ini bertujuan untuk mengetahui pengaruh penggantaian jagung giling dengan sengauk dalam ransum yang mengandung Starpig dan disuplementasikan dengan daun salam (Syzygium polyanthum Walf) terhadap efisiensi penggunaan ransum dan profil lipida darah ayam kampung. Penelitian ini menggunakan rancangan acak lengkap (RAL) dengan tiga perlakuan, yaitu ransum tanpa sengauk, Starpig dan daun salam (A), penggantian 10\% jagung dengan sengauk dan Starpig (B), dan penggantian 10\% jagung dengan sengauk, Starpig dan daun salam (C). Setiap perlakuan dengan tiga ulangan dan setiap ulangan berisi tiga ekor ayam dengan umur dan berat yang homogen. Variabel yang diamati adalah efisiensi penggunaan ransum dan profil lipida darah ayam kampung. Dari hasil penelitian dapat disimpulkan bahwa penggantian jagung giling dengan sengauk yang mengandung Starpig yang disuplementasi dengan daun salam dapat memperbaiki efisiensi penggunaan ransum dan profil lipida darah ayam kampung
\end{abstract}

Kata kunci : jagung giling, sengauk, karkas, efisiensi penggunaan ransum, profil lipida darah, ayam kampung

THE EFFECT OF CORNMEAL SUBSTITUTED WITH SENGAUK IN DIETS
CONTAINSTARPIGSUPPLEMENTED BY SYZYGIUM POLYANTHUM ON FEED
EFFICIENCY AND BLOOD LIPID PROFILE OFKAMPOENG CHICKEN

ABSTRACT

The study was conducted to know the effect of corn substitution with sengauk in diets contain Starpig supplemented by Syzygium polyanthum walf on feed efficiency and blood lipid profile of kampoeng chicken. This experiment was using a completely randomized design (CRD) and assigned to three treatments as of: diets without sengauk,Starpig dan Syzygium polyanthum as control (A), diets containing 10\% corn meal substitution with sengauk and Starpig(B), diets containing 10\% corn meal substitution with sengauk, Starpig and Syzygium polyanthum(C). Three birds were used in each treatment with three replicates. The variables observed were feed efficiency and blood lipid profile ofkampoeng chickens. It showed that corn meal substitution into sengauk in the diets contain Starpig and Syzygium polyanthum supplemented can improve feed efficiency and blood lipid profile of the kampoeng chickens.

Key words : corn meal, sengauk, carcass, meat quality, kampoeng chicken

\section{PENDAHULUAN}

Di dalam meningkatkan produktivitas ternak tidak terlepas dari biaya produksi terutama dari makanan yang berkisar 60\% (Nitis, 1980). Untuk itu maka perlu digalakkan pemanfaatan bahan ransum alternatif salah satu diantaranya adalah sengauk. Sengauk adalah nasi sisa dapur atau hasil sampingan dari upacara yadnya berupa iseran atau tumpeng (nasi yang berbentuk bulatan atau lonjong yang digunakan untuk sesaji) yang dikeringkan. Biasanya digunakan sebagai bahan makanan untuk ternak bali atau dibuang begitu saja. Jika diperhatikan kandungan nutrisinya mendekati kandungan nutrisi beras dan bisa digunakan sebagai pengganti jagung giling yang dimanfaatakan sebagai sumber energi di dalam ransum ternak unggas (Murtidjo, 1988). Pilliang (1997) melaporkan pemanfaatan hasil sampingan dari industri atau dari perkebunan/ 
pertanian masih cukup mengandung energi dan protein yang ketersediaannya cukup banyak masih bisa dimanfaatkan sebagai bahan ransum alternatif dan bisa diberikan pada ternak unggas terutama pada ayam kampung.

Ayam kampung merupakan salah satu jenis unggas yang mempunyai potensi besar sebagai sumber protein hewani (daging dan telur) Unggas ini cocok dikembangkan karena mudah beradaptasi dengan kondisi alam di Indonesia. Potensi unggul lainnya dari ayam kampung adalah bahwa daging ayam mempunyai komposisi gizi terutama protein yang setara dengan daging dari jenis unggas lainnya (Murtidjo, 1988). Dewasa ini masyarakat mulai menggemari daging ayam kampung sehingga permintaan daging ayam kampung terus meningkat, namun ayam yang dijual untuk keperluan daging kebanyakan adalah ayam kampung yang jantan, namun ayam yang telah berumur dagingnya alot, dan berlemak maka dalam ransum perlu ditambahkan zat antioksidan (Yadnya, et al., 2013). Salah satu diantaranya adalah daun salam (Syzygium polyanthum Walf) karena didalam daun salam mengandung flavonoid yang bersifat antioksidan (Hembing, 1989). Adanya senyawa flavonoid bersifat antioksidan dan dapat menetralkan radikal bebas, sehingga oksidasilemakoleh radikal bebas bisa dikurangi sehingga kolesterol LDL (Loww Density Lipoprotein) bisa berkurang apalagi di dalam Pignox mengandung unsur Zn yang sangat bermanfaat untuk aktivitas kerja Superoksida dismutase (SOD) yang bermanfaat untuk menetralkan radikal bebas (Kumalaningsih (2008). Yadnya dan Candrawati (2004) melaporkan pemberian tepung daun salam dapat menurunkan total kolesterol dan LDL darah itik bali pada fase pertumbuhan. Untuk meningkatkan penampilan ternak perlu dicoba pemberian Starbio dan Pignox (Starpig).

Starbio dan Pignox (Starpig) yang merupakan probiotik dan mineral yang berguna untuk meningkatkan nilai dan daya cerna pakan yang diberikan, dimana Starbio merupakan salah satu probiotik yang berasal dari koloni mikroba alami. Pemberian probiotik Starbio pada pakan ternak akan meningkatkan kecernaan ransum, kecernaan protein dan mineral fosfor. Sedangkan Pignox merupakan "feed supplement" (bahan pelengkap) buatan pabrik (Piao et al., 1999) yang mengandung mineral $\mathrm{Zn}$ yaitu $20.000 \mathrm{mg} / \mathrm{kg}$ dan $40.000 \mathrm{mg} /$ $\mathrm{kg}$ methionin. Tillman et al. (1989) menyatakan mineral Zn sangat berfungsi sebagai aktivatorenzim dalam proses metabolisme, salah satu enzim tersebut adalah karboksi peptidase yang berperan dalam metebolisme protein, sehingga Pignox dapat membantu kerja dari Starbio agar proses metabolisme lebih meningkat, sehingga penampilannya menjadi lebih baik, terutamapada pertambahan bobot badan bisa meningkat sehingga efisiensi penggunaan ransum bisa ditingkatkan.

Berdasarkan uraian di atas, maka perlu dikaji pengaruh penggantian jagung giling dengan sengauk dalam ransum yang mengandung Starpig disuplementasi dengan daun salam (Syzygium polyanthum Walf) terhadap efisiensi penggunaan ransum dan profil lipida darah ayam kampung. Mengingat belum banyak informasi yang mempublikasikan maka perlu diangkat dalam suatu penelitian.

\section{METODE PENELITIAN}

\section{Ayam}

Ayam yang digunakan pada penelitian ini adalah ayam kampung bali yang berumur satu tahun sebanyak 45 ekor dengan kisaran berat awal yang homogen dipelihara selama 8 minggu. Bibit ayam diperoleh dari Bapak Dewa Gede Darmada, di Desa Ketewel, Kecamatan Sukawati, Kabupaten Gianyar.

\section{Kandang dan Perlengkapan}

Penelitian ini menggunakan kandang sistem battery coloni yang tebuat dari bambu, terdiri atas dua tingkat sebanyak 12 petak, tiap petak berukuran panjang 80 $\mathrm{cm}$, lebar $60 \mathrm{~cm}$ dan tinggi $70 \mathrm{~cm}$. Tiap petak kandang dilengkapi dengan tempat pakan dan tempat minum yang terbuat dari belahan bambu, di bawah lantai kandang diberi alas plastik untuk menampung feses.

\section{Ransum dan Air Minum}

Ransum yang digunakan tersusun atas bahan-bahan: jagung kuning, bungkil kelapa, dedak padi, tepung ikan, kacang kedelai, daun pepaya, daun salam, daun katuk, minyak kelapa, $\mathrm{NaCl}$ dan Starnox. Selama penelitian air minum yang diberikan berasal dari perusahaan air minum (PAM) setempat. Konsumsi ransum dan kandungan zat nutrisi tertera pada Tabel 1 dan 2.

Tabel 1. Komposisi Ransum Ayam Kampung, 12-14 Bulan

\begin{tabular}{llrrr}
\hline \multirow{2}{*}{ No } & Bahan(\%) & \multicolumn{3}{c}{ Perlakuan ${ }^{1}$ ) } \\
\cline { 2 - 5 } & \multicolumn{1}{c}{$\mathrm{A}$} & \multicolumn{1}{c}{$\mathrm{B}$} & \multicolumn{1}{c}{$\mathrm{C}$} \\
\hline 1 & Jagung kuning & 51,36 & 41,36 & 41,36 \\
2 & Bungkil kelapa & 9,31 & 9,31 & 9,31 \\
3 & Dedak padi & 18,66 & 18,66 & 18,16 \\
4 & Tepung ikan & 8,20 & 8,20 & 8,20 \\
5 & Kacang kedelai & 11,97 & 11,97 & 11,97 \\
6 & Daun salam & - & - & 0.5 \\
7 & Sengauk & 10 & 10 & 10 \\
8 & Starpig & - & 1,00 & 1,00 \\
9 & Total & 100,00 & 100,00 & 100,00 \\
\hline
\end{tabular}


Tabel 2. Komposisi Zat Kimia dalam Ransum Ayam Kampong umur $12-14$ bulan

\begin{tabular}{llrrrr}
\hline \multirow{2}{*}{ No. Komposisi Kimia } & \multicolumn{3}{c}{ Perlakuan } & Standar \\
\cline { 3 - 4 } & \multicolumn{1}{c}{$\mathrm{A}$} & \multicolumn{1}{c}{$\mathrm{B}$} & \multicolumn{1}{c}{$\mathrm{C}$} & NRC(1984) \\
\hline 1 & ME(Kcal/kg) & 3007,9 & 2999,37 & 2885,49 & 2900,0 \\
2 & Protein Kasar(\%) & 17,36 & 17,70 & 16,72 & 17 \\
3 & Serat Kasar(\%) & 3,88 & 3,97 & 5,72 & $3-52)$ \\
4 & Lemak Kasar(\%) & 5,74 & 5,92 & 5,66 & $3-6$ \\
5 & Ca(\%) & 0,78 & 0,76 & 0,75 & 0,80 \\
6 & P tersedia(\%) & 0,54 & 0,56 & 0,51 & 0,50 \\
\hline
\end{tabular}

Keterangan :

1) Perlakuan: $A$ = Ransum tanpa mengandung sengauk, daun salam dan Starpig

$\mathrm{B}=$ Ransum yang mengandung $10 \%$ sengauk dan Starpig

$\mathrm{C}=$ Ransum yang mengandung $10 \%$ sengauk, Starpig dan daun salam

2) Dirjen. Peternakan RI (1995)

Kandungan nutrisi dari jagung kuning, bungkil kelapa, kacang kedelai, minyak kelapa dan dedak padi menurut Scott et al. (1982), daun pepaya menurut Hartadi et al., (1990), daun salam menurut Kumalaningsih (2008). Komposisi bahan makanan dapat dilihat pada Tabel 1.

\section{Tempat dan Lama Penelitian}

Penelitian dilaksanakan di Banjar Buluh, Desa Guwang, Kecamatan Sukawati, Kabupaten Gianyar selama 8 minggu dari bulan Juli- September 2011, Penelitian laboratorium dilaksanakan bulan September-Oktober 2011.

\section{Rancangan Percobaan}

Rancangan percobaan yang dipergunakan dalam penelitian ini adalah rancangan acak lengkap (RAL) dengan empat perlakuan, masing-masing perlakuan terdiri atas tiga ulangan dan setiap ulangan berisi tiga ekor ayam kampung yang berumur satu tahun dengan berat yang homogen. Ketiga perlakuan tersebut adalah: ransum tanpa sengauk, Starpig, dan daun salam (A), ransum mengandung 10\% sengauk dan Starpig (B), dan ransum yang mengandung 10\%sengauk, Starpig, dan daun $\operatorname{salam}(\mathrm{C})$.

\section{Variabel yang Diamati}

1. Variabel efisiensi pengunaan ransum meliputi konsumsi ransum, pertambahan bobot badan, dan konversi ransum (FCR $=$ Feed Conversion Ratio) (Tillman et al., 1989).

2. Profil lipida darah meliputi total kolesterol, HDL (High Density Lipoprotein), LDL (Low Density Lipoprotein) dan Trigliserida, menggunakan metode "Enzymatic cholesterol high pereformance "CHOD-PAP KIT (Boehringer, 1993).

\section{Analisis Statistik}

Data yang diperoleh dianalisa dengan sidik ragam, apabila terdapat hasil yang berbeda nyata $(\mathrm{P}<0,05)$ diantara perlakuan maka analisis dilanjutkan dengan uji jarak berganda dari Duncan (Steel dan Torrie, 1989).

\section{HASIL DAN PEMBAHASAN}

\section{Efisiensi Penggunaan Ransum Ayam Kampung}

Konsumsi ransum pada ayam kampung yang mendapatkan ransum tanpa sengauk, Starping dan daun salam (perlakuan A) adalah 5315,oo g/ekor selama 8 minggu (Tabel 3). Penggantian 10\% jagung giling dengan sengauk dalam ransum yang mengandung Starpig (perlakuan B), dan penggantian 10\% jagung giling dengan sengauk, Starpig dan daun salam (perlakuan C) dapat meningkatkan konsumsi ransum secara nyata $(\mathrm{P}<0,05)$ dibandingkan dengan pemberian perlakuan kontrol (perlakuan A). Peningkatan konsumsi ransum disebabkan adanya Starpig yang mengandung Starbio dan Pignox serta daun daun salam yang menyebabkan ransum menjadi lebih palatebel, sehingga ransum yang dikonsumsi lebih banyak untuk memenuhi kebutuhan akan energi dan zat nutrisi lainnya (Wahyu, 1992).

Peningkatan konsumsi ransum diikuti oleh peningkatan bobot potong, pada perlakuanA bobot poting ayam kampung adalah 1380,oo g/ekor (Tabel 3). Pemberian perlakuan $\mathrm{B}$ dan $\mathrm{C}$ dapat meningkatkan bobot potong secara nyata $(\mathrm{P}<0,05)$ daripada pemberian perlakuan A. Adanya enzim-enzim dalam Starbio diantaranya enzim selulase, protease, dan lipase yang dapat membantu dalam proses pencernaan (Zainuddin et al., 1995), sehingga semakin banyak zat nutrisi yang dapat diserap yang menyebabkan pemberian perlakuan B dan $\mathrm{C}$ bobot potongmya lebih tinggi daripada pemberian perlakuan A

Tabel 3. Subsitusi Jagung Giling dengan Sengauk dalam Ransum yang Mengandung Starpig Disuplementasi dengan Daun Salam (Syzygium polyanthum)terhadap Efisiensi Penggunaan Ransum Ayam Kampung

\begin{tabular}{lrrrc}
\hline \multirow{2}{*}{\multicolumn{1}{c}{ Variabel }} & \multicolumn{4}{c}{ Perlakuan } \\
\cline { 2 - 5 } & \multicolumn{1}{c}{$\mathrm{A}$} & \multicolumn{1}{c}{$\mathrm{B}$} & \multicolumn{1}{c}{$\mathrm{C}$} & SEM \\
\hline Konsumsi ransum (g/ekor) & $5315,00 \mathrm{c}$ & $5373,33 \mathrm{~b}$ & $5399,00 \mathrm{a}$ & 2,38 \\
Berat Potong(g/ekor) & $1380,00 \mathrm{c}$ & $1390,00 \mathrm{~b}$ & $1580,00 \mathrm{a}$ & 2,97 \\
Pertambahan bobot badan (g/ekor) & $360,33 \mathrm{~b}$ & $374,00 \mathrm{~b}$ & $468,00 \mathrm{a}$ & 4,74 \\
Feed Conversion Rasio (FCR) & $14,74 \mathrm{a}$ & $14,38 \mathrm{a}$ & $11,54 \mathrm{~b}$ & 0,27 \\
\hline
\end{tabular}

Keterangan :

1) A: Ransum kontrol; B: Ransum mengandung $10 \%$ sengauk yang mengandung Starpig, dan C: Ransum mengandung 10\% sengauk yang mengandung Starpig dan daun salam.

2) SEM adalah Standard Error of the Treatment Means.

3) Nilai dengan huruf yang sama pada baris yang sama menunjukkanperbedaanyang nyata $(P<0,05)$

Yadnya et al., (2013) melaporkan bahwa pemberian ransum yang mengandung daun ubi jalar ungu sebagai sumber antioksidan yang disuplementasi dengan Starpig dapat meningkatkan bobot potong pada itik umur 23 minggu.

Feed Conversion Rasio (FCR) pada itik yang 
mendapatkan perlakuan A adalah 14,74 (Tabel 3). Substitusi $10 \%$ jagung giling dengan senagauk dan Starpig (B) dapat menurunkan FCR secara tidak nyata ( $\mathrm{P}>0,05)$, sedangkan substitusi 10\% jagung giling dengan sengauk, Starping dan daun salam (C) dapat menurunkan FCR secara nyata $(\mathrm{P}<0,05)$ dibandingkan dengan pemberian perlakuan A. Penurunan FCR pada pemberian perlakuan $\mathrm{C}$, karena adanya unsur $\mathrm{Zn}$, dan asam amino metionin pada Pignox dapat menjngkatkan aktivitas dari Superoksida dismutase (SOD), sehingga kemampuan untuk menstabilkan radikal bebas semakin besar (Kumalaningsih. 2008), sehingga zat nutrisi yang termanfaatkan semakin banyak, terbukti dari pertambahan bobot badan pada perlakuan lebih besar daripada pemberian perlakuan A atau B. Yadnya dan Candrawati (2004) melaporkan pemberian ransum yang mengandung daun salam sebagai sumber antioksidan yang disuplementasi dengan Starbio dapat meningkatkan pwrtambahan bobot badan dan meningkatkan efisiemsi penggunaan ransum.

\section{Profil Lipida Darah Ayam Kampung}

Total kolesterol darah pada itik A adalah 198,3 $\mathrm{mg} / \mathrm{dl}$ (Tabel 4). Pemberian perlakuan B dan C dapat menurunkan total kolesterol darah sebesar 11,34\% dan 20,32\% $(\mathrm{P}<0,05)$ dibandingkandengan pemberian perlakuan A.

Tabel 4. Substitusi Jagung giling dengan sengauk dalam ransum yang mengandung Starpig disuplementasi dengan Daun Salam terhadap Profil Lipida Darah Ayam Kampung.

\begin{tabular}{lccc}
\hline \multirow{2}{*}{ Variabel } & \multicolumn{3}{c}{ Perlakuan } \\
\cline { 2 - 4 } & A & B & C \\
\hline Total kolesterol(mg/dl) & $198,30 a$ & $175,80 \mathrm{~b}$ & $158,00 \mathrm{c}$ \\
HDL( $\mathrm{mg} / \mathrm{dl})$ & $95,60 \mathrm{c}$ & $103,66 \mathrm{~b}$ & $108,00 \mathrm{a}$ \\
LDL(mg/dl) & $82,93 \mathrm{a}$ & $55,86 \mathrm{~b}$ & $38,86 \mathrm{c}$ \\
TAG( mg/dl) & $98,85 \mathrm{a}$ & $81,40 \mathrm{~b}$ & 53,20 \\
\hline
\end{tabular}

Keterangan :

1) A: Ransum kontrol; B: Ransum mengandung $10 \%$ sengauk yang mengandung Starpig , dan C: Ransum mengandung $10 \%$ sengauk yang mengandung Starpig dan daun salam.

2) SEM adalah Standard Error of the Treatment Means.

3) Nilai dengan huruf yang sama pada baris yang sama menunjukkanperbedaanyang nyata $(\mathrm{P}<0,05)$

High Density Lipoprotein (HDL) darah pada itik A adalah 95,6 mg/dl (Tabel 4). Pemberian perlakuan B dan $\mathrm{C}$ dapat meningkatkan kadar HDL darah sebesar $8,43 \%$ dan 13,49 \% secara statittik berbeda nyata $(\mathrm{P}<0,05)$. Low Density Lipoprotein (LDL) darah itik A adalah82,93 mg/dl (Tabel 4). Pemberian perlakuan $\mathrm{B}$ dan $\mathrm{C}$ dapat menurunkan LDL sebesar $32,64 \%$ dan $53,14 \%(\mathrm{P}<0,05)$ dibandingkan dengan pemberian perlakuan A.

Try Acyl Glycerol (TAG) pada darah itik A adalah 98,85mg/dl (Tabel 4). Pemberian perlakuan B dan C dapat menurunkan kadar TGA darah ayam kampung sebesar $17,18 \%$ dan 46,18\% $(\mathrm{P}<0,05)$ dibandingkan dengan pemberian perlakuan $\mathrm{A}$.

Pemberian tepung daun salam dalam ransum yang mengandung sengauk dan Starpig dapat menurunkan kadar total kolesterol dan LDL serum darah serta dapat meningkatkan HDL Darah. Di dalam daun salam mengandung senyawa flavonoid yang bersifat antioksidan, zat antioksidan dapat menurunkan kolesterol LDL didalam tubuh.

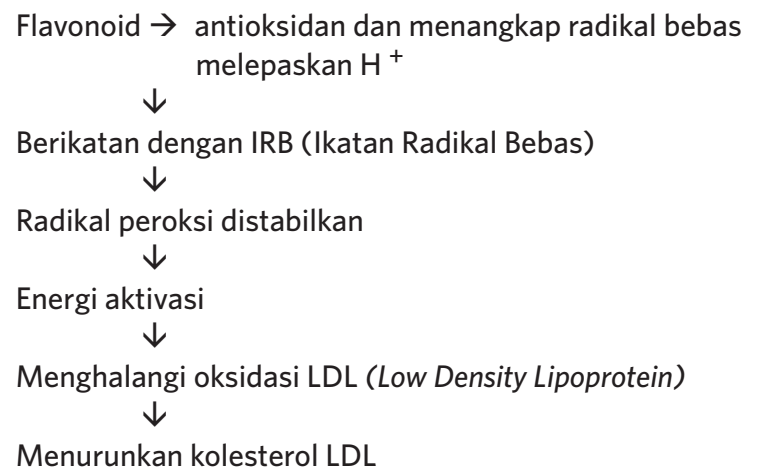

Gambar 1. Cara kerja flavonoid untuk menurunkan kolesterol (Anon,2010c)

Gambar 1 memperlihatkan cara kerja flavonoid sebagai zat antioksidan yang dapat menurunkan kolesterol LDl secara bertahap. Akibat dari penurunan kadar LDL dalam darah maka kadar HDL akan naik dan menuju ke hati. Di dalam hati akan terjadi perombakan daripada kolesterol menjadi asam-sam empedu yang akan dibawa ke kantong empedu untuk dimanfaatkan lebih kanjut untuk kebutuhan metabolisme di dalam tubuh (Murray et al., 2009). Sumardika dan Jawi (2010) telah mencoba pemberian ekstrak dari daun ubi jalar sebagai sumber antioksidan yang diberikan pada mencit yang hasilnya ternyata dapat menurunkan total kolesterol, LDL serum darah dan dapat meningkatkan kandungan HDL serum darah mencit.

Menurut Argawa dan Rao (2000), penurunan kadar kolesterol akibat adanya antioksidan dalam ransum, karena zat antioksidan menetralkan radikal bebas dan menarik lemak atau kolesterol kegugus yang siklis, dan disamping itu zat antioksidan dapat menghambat kerja enzim 3 Hidroksi, 3 Methyl- Gluteryl-Ko,A reduktase, sehingga asam mevalonat yang dihasilkan berkurang, sehingga kolesterol yang diproduksi di hati bisa berkurangyang menyebabkan kolesterol yang tersirkulasi dalam darah bisa berkurang. Yadnya dan Candrawati (2004) melaporkan pemberian ransum yang mengandung daun salam yang disuplementasi dengan Starbio dapat menurunkan total kolesterol dan LDL darah itik pada fase pertumbuhan. Yadnya et al., (2013) melaporkan pemberian ransum yang mengandung 
daun ubi jalar ungu sebagai sumber antioksidan yang disuplementasi dengan Starpig dapat menurunkan total kolesterol dan LDL darah itik umur 23 minggu.

Berdasarkan hasil dan pembahasan dapat disimpulkan bahwa substitusi 10\% jagung giling dengan sengauk dalam ransum yang mengandung Starpig disuplementasi daun salam dapat memperbaiki efisiensi penggunaan ransum ayam kampung dan profil lipida darah ayam kampung.

\section{UCAPAN TERIMA KASIH}

Terima kasih penulis haturkan kepada Rektor Universitas atas bantuan dana yang telah diberikan melalui penelitian Dosen Muda Tahun Anggaran 2011 melalui Lembaga Penelitian dan Pengabdian kepada Masyakat,Universitas Udayana, sehingga penelitian dan laporan penelitian dapat terlaksana sebagaimana mestinya.

\section{DAFTAR PUSTAKA}

Argawa, L. S and Rao, A.V. 200o. Role of Antioxidant Lycopene in Cancerheart deseases. J.Coll.Nutr. 19 (5) : 563- 9 .

Boehringer, N.D. 1993. Enzimatic Cholesterol High Performance CHOD-PAP KIT, France SA 39240

Dirjen Peternakan, RI. 1975. Peraturan Batasan Kandungan Nutrien pada Pakan Ayam. Lapiran Surat Keputusan Direktorat Jendral Peternakan Republik Indonesia No. 120/KPTS/DJP/1975, Tanggal 16 Agustus 1975

Hartadi, H., S. Reksohadiprodjo, dan Tillman A.D. 1990. Tabel komposisi pakan untuk Indonesia. Gadjah Mada University, Press Yogyakarta.

Hembing, W. K. 1998. Pilih daun salam atau daun ubi jalar. Kesehatan Umat. No. 32. Tahun III. 2 Maret.

Kumalaningsih, S. 2008. Antioksidan SOD (Super Oksida Dismutase). Anti Oxidant Center.com. http:/antioksidancenter.com [10 Januari 2008].

Murray,B.K., Granner, dan Rodwell V.W. 2009. Biokimia Harper. EDISI 27. Penerbit buku Kedokteran,EGC,Jakarta.

Murtidjo, B. A. 1988. Mengelola Itik. Penerbit Kanisius, Yogyakarta.
Nitis IM. 1980. Makanan Ternak Salah Satu Sarana untuk Meningkatkan Produksi Ternak. Pidato Ilmiah Pengukuhn Guu Besar dalam Ilmu Makanan Ternak, FKHP,Universitas Udayana, Denpasar.

Piao, X.S., Han I. K., Kim J. H., Cho W.T., Kim Y.H. and Liang C. 1999. Effects of Kemzyme, Phytase and Yeast.

Pilliang, W.G. 1997. Strategi Penyediaan Pakan Berkelanjutan melalui Pemanfaatan Energi Alternatif. Orasi Ilmiuah Guru Besar Tetap Ilmu Nutrisi Ternak. IPB Bogor, 5 Juli 1007,

Scott, M. L, Neiheim, M, C. and Young R.J. 1982. Nutrition of the Chickens M. K. Scott and Associates, New York.

Steel, R. G. D. and Torrie J. H. 1989. Principles and Procedures of Statistics, ${ }^{\text {nd }}$ Ed. McGraw-Hill International Book Co. London.

Sumardika, I W. dan Jawi I M. 2011. Pengaruh pemberian ekstrak daun ubi jalar ungu (Ipomoea batatas L) terhadap profil lipida dan Superoksida dismutase (SOD) serum darah mencit. Prosiding International, 3 rd International Conference on Biosciences and Biotechnology, Bali. September 21 - 22, 2011.

Tillman, A. D., Hartadi H., Reksodoprojo S., Prawiro Kusumo S., dan Lebdosoekojo S. 1998. Ilmu Makanan Ternak Dasar. Gadjah Mada University Press, Yogyakarta.

Wahyu. 1989. Ilmu Nutrisi Unggas. Gajah Mada University Press. Yogyakarta.

Yadnya, T. G. B. dan. Candrawati D. P. M. A. 2004. Suplementasi probiotik starbio dalam ransum yang mengandung daun salam (Syzygium polyanthum Walp) terhadap berat karkas, persentase bobot ternak karkas, kadar kolesterol darah dan kualitas daging itik Bali Afkir. Prosiding, Seminar Nasional Peran Pendidikan Dalam Meningkatkan Ketangguhan Industri Pangan di Era Pasar Bebas, ISBN: 979-952496-2 PATPI. Malang, 30-31 Juli 2003.

Yadnya,TGB, Ni M. S. Sukamawati dan IW. Wirawan. 2013. Pemanfaatan daun ubi jalar ungu dalam ransum yang disuplementasi dengan Starpig terhadap kadarkolesterol serum darah dan karkas itik Bal. Makalah Seminar di Fakultas Agroindustri, Universitas Mecu Buana, Yogyakarta. (Oktober 2013).

Zainuddin, D., K. Dwiyanto and Suharto. 1995. Utielization of a Proboitic Starboi in Broiler Diet with Different Level of Crude Protein. Buletin of Animal Science. A. Publication of the Animal Husbandry. Gadjah Mada University. Yogyakarta. 